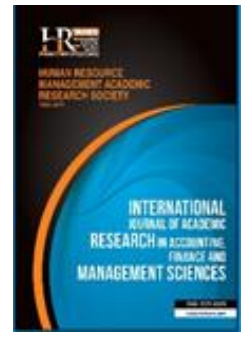

International Journal of Academic Research in Accounting, Finance and Management Sciences

Vol. 8, No.3, July 2018, pp. 265-276

E-ISSN: 2225-8329, P-ISSN: 2308-0337

(c) 2018 HRMARS

www.hrmars.com

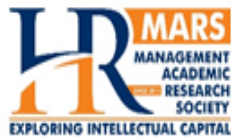

To cite this article: Ohaka, J., Ogaluzor, O.I. (2018). Corporate Social Responsibility Accounting and the Effect of Donations on Profitability of Oil and Gas Companies in Nigeria, International Journal of Academic Research in Accounting, Finance and Management Sciences 8 (3): 265-276.

\title{
Corporate Social Responsibility Accounting and the Effect of Donations on Profitability of Oil and Gas Companies in Nigeria
}

\author{
John OHAKA ${ }^{1}$, Odinakachukwu I. OGALUZOR ${ }^{2}$ \\ 1,2Department of Accountancy, Rivers State University of Science and Technology, Port Harcourt, Nigeria \\ ${ }^{1}$ E-mail: ohaka.john@ust.edu.ng, 2E-mail: oogaluzor@yahoo.co.uk
}

\begin{abstract}
There is a crying need for an in-depth study into the quality, extent of corporate social responsibility (CSR) disclosure and identification of areas for future improvement so that transparency can be ensured, especially in developing countries like Nigeria where CSR practices are limited. Based on this we carried out this study on corporate social responsibility accounting and the effect of donations on profitability of oil and gas companies in Nigeria. The study used a cross sectional survey design to carry out the research. The population of the study was all the oil and gas companies in Nigeria. Data collected were analyzed through the Simple Regression Analysis and Partial Correlation. Results of the study revealed that: Donation significantly affects Return on Equity and Donation significantly affects Net Profit of the oil and gas companies in Nigeria, Hence, from the findings of this work the research concludes that there is a strong positive relationship between CSRA and profitability. And that; Donation significantly affects the Return on Assets of the oil and gas companies in Nigeria; Donation significantly affects the return on equity of the oil and gas companies in Nigeria; Donation significantly affects the Net Profit of the oil and gas companies in Nigeria. Therefore all the null hypotheses have been rejected and the alternative hypotheses accepted. Based on the findings of the study, the following recommendations were made; Companies should carry out operational impact evaluation. This is in order to evaluate the effect of their operation on the community, the environment and the people as this will be able to audit and control their CSR practices. It will help them check unwholesome practices; Companies should report regularly to its stakeholders their corporate social responsibility practices. The companies are too secretive and do not allow the people have insight of most of their activities. Forums should be created where these are reported to the people; Government should consider allowable all arm's length expenditure on corporate social responsibility for tax purposes to enable the companies become completely socially responsible.
\end{abstract}

Key words Corporate Social Responsibility, donations, accounting, profitability of Oil and Gas Companies in Nigeria

Received: 30 Sept $2018 \quad$ (C) The Authors 2018

Revised: 26 Oct 2018 Published by Human Resource Management Academic Research Society (www.hrmars.com)

Accepted: $\quad 30$ Oct 2018 This article is published under the Creative Commons Attribution (CC BY 4.0) license. Anyone may reproduce, distribute, translate and create derivative works of this article (for both commercial and noncommercial purposes), subject to full attribution to the original publication and authors. The full terms of this license may be seen at: http://creativecommons.org/licences/by/4.0/legalcode

\section{Introduction}

Corporate scandals at Enron and WorldCom, Cadbury, NNPC etc. have thrust debates concerning corporate governance and corporate social performance to the forefront of the minds of shareholders, managers, and public policy makers (Uwuigbe, 2011). Traditionally, companies have to focus on strategies for their business operations and profit such as differentiation, diversification, turnaround, concentration and globalization (Awan and Akhtar, 2014). However, recent developments in strategic thinking support the need to add activities that expand out from the company into society (Awan and Akhtar, 2014). Corporations around the world are struggling with a new role, to meet the needs of the present generation without compromising the ability of the next generation to meet their own needs (Babalola, 2013). Since 
the publication of the first separate corporate environmental reports in 1989, the number of companies that has started to publish information on its environmental, social or sustainability policies has increased substantially (Uwuigbe, 2011). Environmental problems have become major headlines of political, economic and corporate discussion due to the negative effects they bring to the stability of the ecosystem (Uwuigbe, 2011), as organizations are being called upon to take responsibility for the ways their operations impact societies and the natural environment (Babalola, 2013). In its stronger form, the concept of Corporate Social Responsibility (CSR) asserts that corporations have an obligation to consider the interests of customers, employees, shareholders, communities, as well as the ecological 'footprint' in all aspects of their operations. These uncontrolled impacts of industrial activities on the environment have created critical ecological challenges on the planet; which has aggravated phenomena like climate change, ozone depletion, over-exploitation of natural resources, air pollution and increase in radioactive water pollution that has resulted to the continues destruction of the water marines thereby disrupting the sustainable development of such environment (Uwuigbe, 2011).

These phenomena have invariably increased external pressure from many stakeholders such as government, financial institutions, social responsible investors and most especially community lobby groups whose activities have constantly created continuous social unrest. Thus, companies have to cope the challenges come from the public and stakeholders in order to get the good reputation, increasing the effectiveness of the companies, improving the performance of the companies, having good relation to the stakeholders, and getting "social permission" to operate their business within societies and communities (Wibowo, 2012). The concept of Corporate Social Responsibility is closely linked with the principle of Sustainable Development, which argues that corporations should make decisions based not only on financial factors such as profits or dividends, but also based on the immediate and long-term social and environmental consequences of their activities (Manescu and Starica, 2008).

At present, firms are seen not only as responsible to their direct owners, i.e. shareholders and debt holders, but to stakeholders as a whole, an enormous step-ahead from the era when corporations were profit maximization entities only (Manescu and Starica, 2008). Thus, corporate social responsibility is viewed not as 'an expedient response to momentary social pressures, but rather a manifestation of deep, far- reaching social changes in our society' (Votaw, 1972, as in Dabbas and Al-rawashdeh, 2012). According to Sapkauskiene and Leitoniene (2014) corporate social responsibility is conceived as an activity policy and practice of organizations (and individuals) when firms voluntarily integrate social and environmental matters into their business and combine them harmoniously with economic interests, and the relationships with all stakeholders are based on the valuable principles of respect for the individual, society and the environment.

In Nigeria, Ajide and Aderemi (2014) observed that the issue of Corporate Social Responsibility (CSR) is deepening among organizations and societies. It is regarded as the organization's activity to make sustainable impact in society, and which in turn has the potential to create positive effect on the business organizations that engage in it (Ajide and Aderemi, 2014). Thus, modern business managers are focusing on the fact that their organizations should extend its activities to the community and not limited only to goods or service (Bakri, 2005, as in Dabbas and Al-rawashdeh, 2012).

\subsection{Statement of the Problem}

In an attempt to study the relationship between corporate social responsibility and financial performance in Nigeria; it was discovered that some companies practice corporate social responsibility without disclosing it in their financial statement while others do not practice it. Also there is no uniformity by those that display it. For example, some companies display it as charity while others call it community project. Ajide and Aderemi (2014) observed that business organizations in Nigeria incur huge expenditures on social responsibility because they regard Corporate Social Responsibility (CSR) as a public relations stunt used by large corporations to look good in front of customers and other stakeholders. However most companies do not find the justification for such, as the relationship between CSR expenditure and financial performance of corporations in developing nations remains unclear. Obi (2013) as in Ajide and Aderemi (2014) noted that in the year 2011, the oil and gas sector spent N9.5 billion on CSR, followed by telecoms with N6.4 billion. The banking industry came in third position with the report that a total of N1.869 billion 
was spent by eight Nigerian banks in 2012 on various community-related projects under corporate social responsibility to identify with the society in which they operate. The figure is about 70 percent of the total CSR expenditure of N3.4 billion by the banking industry in year 2011 with prediction that the figure would double in the next two years due to increased understanding of the concept of CSR. In view of the huge expenditures incurred annually on CSR, it is generally held that corporate social responsibility (CSR) could increase company profits. Different researchers however analyze different aspects of social responsibility and social responsibility itself differs depending on the country context (Sapkauskiene and Leitoniene, 2014). It can also be observed that the majority of studies were performed in developed countries although over the recent years there has been an increase in their number in developing countries as well. The research of corporate social responsibility showed that recently the main focus is paid on disclosure of social information. The problem remains that the different studies provide mixed results about nature and scope of social information, about theories on corporate social information disclosure behavior and about CSR impact to company's reputation and financial performance. There is a crying need for an in-depth study into the quality, extent of corporate social responsibility disclosure and identification of areas for future improvement so that transparency can be ensured, especially in developing countries like Nigeria where CSR studies are limited (Ajide and Aderemi, 2014). While some studies prove a positive association between profitability of firms and CSR expenditures (Olayinka and Temitope 2011; Amole et al., 2012), other studies prove a negative relationship between the two (Bessong and Tapang, 2012). Furthermore, the practice of CSR has been dominated by developments in Western developed countries, such as the United States of America (USA) and the United Kingdom (UK) and it is unclear whether it translates easily into developing and low income countries (Awan and Akhtar, 2014). Thus, a firm cannot ignore the problems of the environment in which it operates (Babalola, 2013). This implies that a firm that wish to continue operation and enjoy customers' loyalty and patronage must seek social audit by scanning the environment it operates and ascertain the needs of the dwellers so as to provide it satisfactorily (Babalola, 2013). Though studies on corporate social responsibility and performance remain rampant, there is a need to reexamine the relationship between corporate social responsibility disclosure and expenditure in financial reports on profitability.

\subsection{Purpose of the Study}

1. To determine the effect of Donation on the Return on Assets (ROA) of the oil and gas companies in Nigeria.

2. To ascertain the effect of Donation on the Return on Equity (ROE) of the oil and gas companies in Nigeria.

3. To ascertain the effect of Donation on the Net Profit of the oil and gas companies in Nigeria.

\section{Literature Review}

\subsection{The Concept of Corporate Social Responsibility (CSR)}

The term Corporate Social Responsibility has no one definition as different scholars at different times try to give their own definition based on the perception of the concept. However we will attempt to define it by looking into different works by different scholars. Buckstein (Retrieved, 2016) in his work states that "there is no exact definition of Corporate Social Responsibility (CSR), nor is there an accepted single method or approach that all companies need to follow. There are multiple variables that can be incorporated into an action plan. Firms must, therefore, develop their own definition of what CSR entails, and formulate an action plan to execute their operations in a socially responsible manner towards their vast network of internal and external stakeholders, including employees, shareholders, creditors, analysts, and the local community".

The "term "corporate social responsibility" is as easily recognizable to consumers as it is to business leaders. But while both parties know of at least a couple of examples of socially active projects that they have confirmed to be CSR initiatives, it is unclear what to expect from something labeled as "CSR"." Tran (2015) However he gave a definition by Denis Leonard and Rodney McAdams, they "offer a broad, yet generally accepted definition: "CSR aims to embrace responsibility for corporate actions and to encourage a positive impact on the environment and stakeholders including consumers, employees, investors, 
communities, and others" (McAdams and Leonard, 2003)". Prieto-Carrón et al. (2005) says that "according to one of the most frequently cited definitions, CSR is 'a concept whereby companies integrate social and environmental concerns in their business operations and in their interaction with their stakeholders on a voluntary basis.' The definition by Commission of the European Communities, Promoting a European framework for corporate social responsibility, green paper (Brussels: European Commission, 2001)" posits "that Corporate social responsibility is voluntary" and can only be carried out if a company voluntarily decides to do it. But there is a level in which they can exercise this option as the host communities might not tolerate lack of CSR from companies operating in their area. Again there are some environmental laws that mandate corporate organizations to carry out measures that will mitigate environmental degradation in the area which they operate. For example The International Law of Environmental Impact Assessment; Environmental Impact Assessment Act of 1992 (EIA Act); Federal Environmental Protection Agency Act of 1988 (FEPA Act); Harmful Wastes (Special Criminal Provisions etc.) Act of 1988 (Harmful Wastes Act). Corporate organization are also participating in CSR through some specialized taxes that they pay e.g. the education tax.

In his work Palmer (2012) also made a good attempt in defining CSR. He said that "with so many conflicting interests and goals of stakeholders, the definition of CSR is not always clear. For the purpose of his study, he defined CSR as "actions that appear to further some social good, beyond the interest of the firm and that which is required by law." In this definition", voluntary aspect of CSR is also emphasized while he further maintained that it is beyond the interest of the firm. Of course it is not every CSR carried out by a company is beyond their interest, in fact we will say that it is as much their interest since it will boost the perception of the company in the eye of the host community, it will bring about a relative peace which will enable the company to operate peacefully and avoid loss of man hour and high security cost due to risk of invasion by the host community. According to Petr et al. (2013) who quoted (Hopkins M. 2007) "There are several definitions of CSR; the non-governmental organization Business of Social Responsibility defines CSR as follows: "Corporate Social Responsibility is a way of doing business that matches or exceeds ethical, legal, commercial and social expectations".

"The broadest definition of Corporate Social Responsibility is concerned with what is - or should be the relationship between global corporations, government of countries and individual citizens. More locally the definition is concerned with the relationship between corporation and the local society in which it resides and operates; another definition is the relationship between a corporation and its stakeholders" (Crowther and Aras, 2008).

Of particular interest and acceptance to the researcher is the new definition offered by European Commission which was also upheld by the Euro Commerce, the retail, wholesale and international trade representative to the EU in a position paper on a renewed EU strategy 2011-14 for Corporate Social Responsibility. CSR is defined as "responsibility of enterprises for their impacts on society". Euro Commerce also stated that "this new definition constitutes a paradigm shift in EU policy on Corporate Social Responsibility. Euro Commerce regrets that the voluntary engagement of companies is apparently no longer seen by the Commission as a key feature of CSR. From Euro Commerce's point of view, the new definition does not do justice to the great voluntary efforts and achievements that can be witnessed in commerce and other sectors. Therefore, Euro Commerce would recommend the Commission to continue to highlight the voluntary nature of CSR in future communications and initiatives".

Yes, even though corporate social responsibility has a lot of voluntary services, we should not also forget that there are legally binding laws that can enforce some CSR if the companies refused to carry out its corporate social responsibility. In fact the word responsibility says it all. The researcher therefore defines corporate social responsibilities as those social and environmental services or activities that must be undertaken by a company to smoothen their operations and also bring about the wellbeing and sustainability of the company, people and the environment in the area they operate thereby affecting the entire universe.

\subsection{Principles of Corporate Social Responsibility}


Crowther and Aras (2008) identified corporate social responsibility as activity and therefore posited that there are three basic principles that together comprise the corporate social responsibility activity. They are: sustainability, accountability, transparency.

\subsubsection{Sustainability}

"Sustainability is concerned with the effect which action taken in the present has upon the options available in the future. The starting point for every definition of sustainability comes from the Brundtland Report, which was published in 1987. This is actually a report named Our Common Future which was produced by the World Commission on Environment and Development. It is generally known however as the Brundtland Report after its chair".

Sustainability looks into the effect of action taken today and the options available in the future. A situation where we use a particular resource in course of our business, we consider whether the resource will be available for future use. The concern is more on resources that have limited supply. Where a resource is limited in quantity and cannot or will be difficult to be recreated, the question of sustainability comes to play. We must know that whatever resources that are used now will no longer be available to be used in the future. Therefore, for sustainability to be of effect, society must use no more than the resource they can regenerate. Raw materials extracted from the ground are finite in nature. For example; coal, oil and so on. Quantity used of these resources will not be available in the future at some point in time there has to be alternative. Sustainability measures the rate in which resources are consumed by an organization in relation to the rate it can regenerate those resources. In order to sustain unsustainable operations we need to plan for the future need of our operations.

\subsubsection{Accountability}

One of the principles recognized by Crowther and Aras (2008) is accountability. For CSR to be active, the company must have a sense of accountability. The company must recognize that its action affects the society and therefore must assume responsibility for such impact on the society. The external environment is affected by the companies' action through emissions, social change, infrastructural sharing and others. The presence of a company in an environment brings about a lot of vices. In our elementary economies one of the disadvantages of siting an industry in a particular place is that it brings about social misfits and increase criminal activities. Crowther and Aras (2008) said that accountability is concerned with an organization recognizing that its actions affect the external environment, and therefore assuming responsibility for the effects of its actions. The concept of accountability advocates for a quantification of the effects of actions taken, both internal and external to the organization. To be more specific the reporting of these quantifications must be made available to all parties affected by those actions. Therefore the effect of the action taken by the organization must be reported to the stakeholders. Not only the effect but the magnitude of it must be made clear. The stakeholders should not be in dark about this. Crowther and Aras (2008) went on to say that this concept therefore indicates acknowledgment that the business is part of a wider societal network and has responsibilities to that entire network rather than just to the owners of the organization.

\subsubsection{Transparency}

"Transparency, as a principle, means that the external impact of the actions of the organization can be ascertained from that organization's reporting and pertinent facts are not disguised within that reporting. Thus all the effects of the actions of the organization, including external impacts, should be apparent to all from using the information provided by the organization's reporting mechanisms. Transparency is of particular importance to external users of such information as these users lack the background details and knowledge available to internal users of such information. Transparency therefore can be seen to follow from the other two principles and equally can be seen to be a part of the process of recognition of responsibility on the part of the organization for the external effects of its actions and equally part of the process of transferring power to external stakeholders" (Crowther and Aras, 2008). 


\subsection{Donation}

Donation is one of the corporate practices that help to enhance the image of the organization thereby leading to the acceptability of the organization. Sufian (2012) identifies 35 areas in which corporate social responsibility can be disclosed. One of it is cash donations by the organization. Mattila (2012) quoting Sen and Bhattacharya, 2001, says that "CSR programs can take many forms, such as diversity initiatives, recycling programs, the use of green materials, support of community events, and donations of money to charitable causes" In order to get competitive advantage over competitors and gain corporate image boosting, companies have used donations as part of their CSR strategies. In Weber (2008), he classifies donation into one time and continuous donation, according to him; "One-time CSR costs include one-time donations such as the donations granted to support the Tsunami victims in 2004. One-time CSR costs also include investment costs e.g., for the installation of smoke filters that are beyond legal requirements, and other one-time costs caused by the CSR activities in scope. Continuous CSR costs include donations intended to continuously support a certain cause and fees such as license fees to use certain labels or patents, which are paid on a continuous basis" Folse et al. (2010) shows that firm donation amounts do indeed improve campaign participation intentions. Further, the effects were fully mediated by consumer inferences. Donation can be monetary (Cash Donations) or non-monetary such as food stuff, clothing, houses, relief material etc.

\subsubsection{Factors That Influence Donation Behavior}

Mattila (2012) identified three factors that influence donation:

Status: The status of the donor affects the value or amount donated, the proximity of the cause: How close the cause of donation is to the donor also affects donation. And in (Graziano et al., 2007) as quoted by Mattila (2012); empathy towards the cause have also been linked to donation behaviors.

\subsubsection{Characteristics of Donations}

Statutory Board Financial Reporting Standard Guidance Note 2 Accounting and Disclosure for Donations stated three distinguishing characteristics of donations.

i. They are non-reciprocal transfers;

ii. They involve transfers from entities; and

iii. These contributions are voluntary. It went ahead to explain that though they are generally nonreciprocal, however, there may be instances where nominal consideration is provided by the receiver to the donors.

\subsubsection{Accounting for Donation}

"Donations should be recorded in a company's general ledger; just as any other major financial transaction is recorded. Whether money is coming in or whether it is going out, the general ledger helps to keep all of those core transactions in one central location" (Lewis, 2016). According to Statement of Financial Accounting Standards No. 116, "Contributions made shall be recognized as expenses in the period made and as decreases of assets or increases of liabilities depending on the form of the benefits given. For example, gifts of items from inventory held for sale are recognized as decreases of inventory and contribution expenses, and unconditional promises to give cash are recognized as payables and contribution expenses. Contributions made shall be measured at the fair values of the assets given or, if made in the form of a settlement or cancellation of a donee's liabilities, at the fair value of the liabilities canceled". In Ayuwo (2011) she stated that though Companies and allied matters act 1990 requires that a part of the financial statement of the company, the Director's report should reflect the efforts of the company in socio-economic scheme of things. The report is to include issues such as: charity; employment of disabled persons, health, safety and welfare at work of the employee and employees' involvement in the running of the company and their training. However, giving information about socio-economic activities of the corporation in the directors' Report does not satisfy the yearning of quantifying these costs and 
incorporating them in the financial statement. She stated that accounting for corporate social responsibility provides more comprehensive information for an informed decision making. 


\section{Research Methodology}

\subsection{Research Design}

The study made use of cross sectional survey design. In this type of study, subjects are contacted at a fixed point in time and relevant information is obtained from them. On the basis of this information, they are then classified as having or not having the attribute of interest" (Anonymous Retrieved 2017).

\subsection{Population of the Study}

The target population is the entire group of items which the researcher wishes to study and about which he plans to generalize (Baridam 2001). The population of this study is the entire oil and gas companies operating in Nigeria. Due to inaccuracy of data available and the fact that most of the oil and gas companies in Nigeria are just portfolio companies that you can neither trace nor access their offices, the researcher through judgment used three oil and gas companies which are most relevant to the study and are both traceable and accessible. Total E\&P Nigeria Limited, Nigerian Agip Oil Company Limited and Schlumberger Nigeria Limited were used in the study. 137 staff consisting of staff in the finance, human resources and community affairs, safety and health environment of the companies: Agip, Total and Schlumberger. These are Departments that can adequately supply information on CSR and CSRA and also profitability. Specifically all the members of staff of these Departments were not involved. Only those whose job has direct bearing on the study were selected. Junior staff, supervisors and management staff in the three Departments who have adequate knowledge of the variables studied were interviewed. These made up the target population.

\subsection{Sample Size}

The sample of the study is 102 staff. This was drawn from the three companies using proportional random sampling technique. The sample size was obtained by using the Taro Yamane formula as follows:

$$
n=\frac{N}{1+N(e) 2}
$$

Where $\mathrm{n}=$ Sample size; $\mathrm{N}=$ Population size; $\mathrm{E}=$ Level of significant.

$$
n=\frac{137}{1+137(0.05)^{2}}, n=102
$$

Thus the sample size $(n)$ for the study is $=102$.

\subsection{Data Collection Method}

Primary and secondary source of data collection were used for the purpose of this study. Primary data collection involved the administration of copies of questionnaire to respondents in the three departments of the companies under investigation. The secondary data collection method involved the review of relevant literature.

\subsection{Questionnaire Design}

The questionnaire was designed to be clear, concise, factual and easy to achieve the purpose of the research. The Likert type questionnaire with five points ranging from strongly agree to strongly disagree were used to obtain data from the respondents. The questionnaire was made up of two sections (i.e. section $A$ and $B$ ). Section A contained questions on the personal data of the respondents while section $B$ contained questions based on the hypothesis and stated research questions.

\subsection{Test of Validity}

The researcher after designing the questionnaire reviewed each items to assess its content as to the extent it relates to the variable under investigation. The researcher achieved the validity of this study by seeking for opinions of experts and the research supervisors for proper scrutiny and evaluation of the survey instrument so as to ensure its relationship with the variables under investigation. The instrument 
was subjected to face and content validation by experts in the field of Accounting. This was to ensure clarity in words in writing the items of the questionnaire. Also, it aimed at ensuring that the items of the questionnaire cover the content (variables) to be measured. Afterwards, the instrument was sent to experts in educational Measurement and Evaluation for construct validation.

\subsection{Test of Reliability}

The instrument being a multivariate instrument has three sections namely sections $A, B$ and $C$ measuring the demographic data, the independent variables and the dependent variables. The reliability of instrument was established using test re-test method.

\subsection{Data analysis Technique}

The research questions were answered and hypotheses tested with one or more of the following statistics: mean, standard deviations, simple regression analyses and partial correlation as it applies to each situation. These were analyzed with the Statistical Package for Social Science (SPSS) Version 21.0. Testing of hypotheses was done at 0.05 level of significance. Hence, if the probability levels which was computer generated, is equal to or less than 0.05 , the null hypothesis is rejected and the alternative hypothesis accepted and vice versa.

\subsection{Operational Measure of Variable}

This study examines two major variables: the independent and dependent variables. The study is basically on the test of the hypothesis whether there is a relationship between the independent variable and the dependent variable. The independent and dependent variable under empirical test are CSRA and profitability. To score the responses, the modified five point Likert scale instrument were used in the design. This is designed to measure the degree of intensity of the effect of the independent variables. The modified five-point Likert scales are designed as follows: Strongly agreed -5 , agreed -4 , neutral 3, disagree 2 , strongly disagree-1 for positive questions while the reverse is the case for negative questions.

\section{Data Presentation, Analysis and Discussion of Findings}

\subsection{Data Analysis}

Table 1. Numbers and Percentages of Questionnaire Distributed and Retrieved

\begin{tabular}{|l|c|c|c|c|}
\hline \multicolumn{1}{|c|}{ Companies } & No. Distributed & Percentage & No. Retrieved & Percentage \\
\hline AGIP & 45 & 44.1 & 43 & 44.3 \\
\hline TOTAL & 48 & 47.1 & 45 & 46.4 \\
\hline SCHLUMBERGER & 9 & 8.8 & 9 & 9.3 \\
\hline TOTAL & $\mathbf{1 0 2}$ & $\mathbf{1 0 0}$ & $\mathbf{9 7}$ & $\mathbf{1 0 0}$ \\
\hline
\end{tabular}

Source: Research Survey 2016

The Influence of Donation on Return on Assets of Oil and Gas Companies in Nigeria

Table 2. Descriptive Statistics of Responses on Donation and Return on Assets (ROA)

\begin{tabular}{|c|c|c|c|}
\hline & Mean & Std. Deviation & N \\
\hline ROA & 19.2474 & 2.86876 & 97 \\
Donation & 20.5464 & 2.67325 & 97 \\
\hline
\end{tabular}

Source: Research Output 2016

Table 2 above shows that 97 individuals responded to the items of the questionnaire on Donation and Return on Assets. Scores on Return on Assets had a mean of 19.2474 and a standard deviation of 2.86876. Scores on Donation had a mean of 20.5464 and a standard deviation of 2.67325 .

Table 3 shows that 97 respondents were used in the analysis. The Pearson correlation analysis yielded a coefficient of .885 which indicates a high positive relationship between responses on Donation 
and Return on Assets. This implies that as the respondents' scores on Donation increase, their scores on the Return on Assets increase likewise.

Table 3. Correlation Analysis of the Responses on Donation and Return on Assets

\begin{tabular}{|ll|c|c|}
\hline & & ROA & Donation \\
\hline \multirow{2}{*}{ Pearson Correlation } & ROA & 1.000 & .885 \\
& Donation & .885 & 1.000 \\
Sig. (1-tailed) & ROA &. & .000 \\
& Donation & .000 &. \\
$\mathrm{~N}$ & ROA & 97 & 97 \\
& Donation & 97 & 97 \\
\hline
\end{tabular}

Source: Research Output 2016

Table 4.Regression Analysis of the Responses on Donation and Return on Assets

\begin{tabular}{|c|c|c|c|c|c|}
\hline \multirow{2}{*}{ Model } & \multirow{2}{*}{$\mathrm{R}$} & \multirow{2}{*}{ R Square } & \multicolumn{3}{|c|}{ Change Statistics } \\
\cline { 4 - 6 } & & & $\mathrm{df1}$ & $\mathrm{df2}$ & Sig. F Change \\
\hline 1 & $.885^{\mathrm{a}}$ & .784 & 1 & 95 & .000 \\
\hline
\end{tabular}

Source: Research Output 2016

Table 4 above shows the summary table of the regression analysis of the influence of Donation on Return on Assets. The coefficient of correlation $(r)=.885$ while the coefficient of determinate on $\left(R^{2}\right)=$ .784. This implies that about $78.4 \%$ changes in Return on Assets are accounted for by changes in Donation. Hence the remaining $21.6 \%$ changes in Return on Assets are due to changes in other factors than Donation. It therefore implies that Donation has high positive influence on the Return on Assets. This provides an answer to the research question four which asks: "To what extent does Donation affect the Return on Assets of the organisations?" Table 4 also shows that the correlation coefficient of .885 is significant at 0.05 level of significance because the sig. for 2 -tailed (at $\mathrm{df}=1,95$ ) which equals $0.000<0.05$. Therefore, reject the null hypothesis which states that Donation does not significantly influence Return on Assets of the oil and gas companies in Nigeria. Hence, accept the alternative hypothesis.

The Influence of Donation on Return on Equity of Oil and Gas Companies in Nigeria

Table 5. Descriptive Statistics of Responses on Donation and Return on equity (ROE)

\begin{tabular}{|c|c|c|c|}
\hline & Mean & Std. Deviation & N \\
\hline ROE & 19.3505 & 2.76527 & 97 \\
DONATION & 20.5464 & 2.67325 & 97 \\
\hline
\end{tabular}

Source: Research Output 2016

Table 5 above shows that 97 individuals responded to the items of the questionnaire on Donation and Return on equity. Scores on Return on equity had a mean of 19.3505 and a standard deviation of 2.76527. Scores on Donation had a mean of 20.45464 and a standard deviation of 2.67325 .

Table 6. Correlation Analysis of the Responses on Donation and Return on equity

\begin{tabular}{|ll|c|c|}
\hline & & ROE & DONATION \\
\hline \multirow{2}{*}{ Pearson Correlation } & ROE & 1.000 & .794 \\
& DONATION & .794 & 1.000 \\
Sig. (1-tailed) & ROE &. & .000 \\
& DONATION & .000 &. \\
$\mathrm{~N}$ & ROE & 97 & 97 \\
& DONATION & 97 & 97 \\
\hline
\end{tabular}

Source: Research Output 2016 
Table 6 shows that 97 respondents were used in the analysis. The Pearson correlation analysis yielded a coefficient of .794 which indicates a high positive relationship between responses on Donation and Return on equity. This implies that as the respondents' scores on Donation increase, their scores on the Return on equity increase likewise.

Table 7. Regression Analysis of the Responses on Donation and Return on equity

\begin{tabular}{|c|c|c|c|c|c|}
\hline Model & \multirow{2}{*}{$\mathrm{R}$} & \multirow{2}{*}{ R Square } & \multicolumn{3}{|c|}{ Change Statistics } \\
\cline { 4 - 6 } & & & $\mathrm{df1}$ & $\mathrm{df2}$ & Sig. F Change \\
\hline 1 & $.794^{\mathrm{a}}$ & .630 & 1 & 95 & .000 \\
\hline
\end{tabular}

\section{Source: Research Output 2016}

Table 7 above shows the summary table of the regression analysis of the influence of Donation on Return on equity. The coefficient of correlation $(r)=.794$ while the coefficient of determination $\left(R^{2}\right)=.630$. This implies that about $63.0 \%$ changes in Return on equity are accounted for by changes in Donation. Hence the remaining $37.0 \%$ changes in Return on equity are due to changes in other factors than Donation. It therefore implies that Donation has high positive influence on the Return on equity. This provides an answer to the research question five which asks: "To what extent does Donation affect the return on equity of the organisations?"

Table 7 also shows that the correlation coefficient of .794 is significant at 0.05 level of significance because the sig. for 2-tailed (at $d f=1,95$ ) which equals $0.000<0.05$. Therefore, reject the null hypothesis which states that Donation does not significantly influence return on equity of the oil and gas companies in Nigeria. Hence, accept the alternative hypothesis.

\section{The Influence of Donation on Net Profit of Oil and Gas Companies in Nigeria}

Table 8. Descriptive Statistics of Responses on Donation and Net Profit

\begin{tabular}{|l|c|c|c|}
\hline & Mean & Std. Deviation & N \\
\hline Net Profit & 19.1546 & 2.50142 & 97 \\
Donation & 20.5464 & 2.67325 & 97 \\
\hline
\end{tabular}

Source: Research Output 2016

Table 8 above shows that 97 individuals responded to the items of the questionnaire on Donation and Net Profit. Scores on Net Profit had a mean of 19.1546 and a standard deviation of 2.50142. Scores on Donation had a mean of 20.5464 and a standard deviation of 2.26375 .

Table 9. Correlation Analysis of the Responses on Donation and Net Profit

\begin{tabular}{|ll|c|c|}
\hline & & Net Profit & DONATION \\
\hline Pearson Correlation & Net Profit & 1.000 & .752 \\
& Donation & .752 & 1.000 \\
Sig. (1-tailed) & Net Profit &. & .000 \\
& Donation & .000 &. \\
$\mathrm{~N}$ & Net Profit & 97 & 97 \\
& Donation & 97 & 97 \\
\hline
\end{tabular}

Source: Research Output 2016

Table 9 shows that 97 respondents were used in the analysis. The Pearson correlation analysis yielded a coefficient of .752 which indicates a high positive relationship between responses on Donation and Net Profit. This implies that as the respondents' scores on Donation increase, their scores on the Net Profit increase likewise. 
Table 10. Regression Analysis of the Responses on Donation and Net Profit

\begin{tabular}{|c|c|c|c|c|c|}
\hline Model & \multirow{2}{*}{$R$} & \multirow{2}{*}{ R Square } & \multicolumn{4}{|c|}{ Change Statistics } \\
\cline { 4 - 6 } & & & $\mathrm{df1}$ & $\mathrm{df} 2$ & Sig. F Change \\
\hline 1 & $.752^{\mathrm{a}}$ & .566 & 1 & 95 & .000 \\
\hline
\end{tabular}

Source: Research Output 2016

Table 10 above shows the summary table of the regression analysis of the influence of Donation on Net Profit. The coefficient of correlation $(r)=.752$ while the coefficient of determination $\left(R^{2}\right)=.566$. This implies that about $56.6 \%$ changes in Net Profit are accounted for by changes in Donation. Hence the remaining $43.4 \%$ changes in Net Profit are due to changes in other factors than Donation. It therefore implies that Donation has high positive influence on the Net Profit. This provides an answer to the research question five which asks: "To what extent does Donation affect the Net Profit of the organisations?"

Table 10 also shows that the correlation coefficient of .752 is significant at 0.05 level of significance because the sig. for 2-tailed (at $d f=1,95$ ) which equals $0.000<0.05$. Therefore, reject the null hypothesis which states that Donation does not significantly influence Net Profit of the oil and gas companies in Nigeria. Hence, accept the alternative hypothesis.

\subsection{Summary of Findings}

1. Donation significantly affects the Return on Assets of the oil and gas companies in Nigeria.

2. Donation significantly affects the return on equity of the oil and gas companies in Nigeria.

3. Donation significantly affects the Net Profit of the oil and gas companies in Nigeria.

\section{Conclusions}

From the findings of this work the research concludes that there is a strong positive relationship between CSRA and profitability. Also;

Donation significantly affects the Return on Assets of the oil and gas companies in Nigeria.

Donation significantly affects the return on equity of the oil and gas companies in Nigeria.

Donation significantly affects the Net Profit of the oil and gas companies in Nigeria.

Therefore all the null hypotheses have been rejected and the alternative hypotheses accepted.

\section{Recommendations}

Based on the findings of the study, the following recommendations were made:

1. Companies should carry out operational impact evaluation. This is in order to evaluate the effect of their operation on the community, the environment and the people. This will be able to audit and control their CSR practices. It will help them check unwholesome practices.

2. Companies should report regularly to its stakeholders their corporate social responsibility practices. The companies are too secretive and do not allow the people have insight of most of their activities. Forums should be created where these are reported to the people.

3. Government should consider allowable all arm's length expenditure on corporate social responsibility for tax purposes to enable the companies become completely socially responsible.

\section{References}

1. Ajide, F. M. \& Aderemi, A. A. (2014). The effects of corporate social responsibility activity disclosure on corporate profitability: Empirical evidence from Nigerian commercial banks. IOSR Journal of Economics and Finance (IOSRJEF), 2(6), 17-25.

2. Awan, A. G., \& Akhtar, N. (2014). The Impact of Corporate Social Responsibility (CSR) on Profitability of Firms: A Case Study of Fertilizer \& Cement Industry in Southern Punjab, Pakistan. Retrieved from http://www.eajournals.org/wp-content/uploads/The-Impact-ofCorporate-Social-Responsibility-CSRon-Profitability-of-Firms-A-Case-Study-ofFertilizer-Cement-Industry-in-Southern-Punjab-Pakistan.pdf. 
3. Babalola, Y. A. (2012). The impact of corporate social responsibility on firms' profitability in Nigeria. European Journal of Economics, Finance and Administrative Sciences, 45(1), 39-50.

4. Babalola, Y. A. (2013). An Impact of Social Audits on Corporate Performance: Analyses of Nigerian Manufacturing Firms. Research Journal of Finance and Accounting, 4(3), 96- 101.

5. Bessong, P.K. \& Tapang, A.T. (2012). Social responsibility cost and its influence on the profitability of Nigerian banks. International Journal of Financial Research, 3(4), 1-5.

6. Crowther \& Aras (2008). Corporate social responsibility. David Crowther and Guler Aras Venture Publishing ApS ISBN 978-87-7681-415-1

7. Lewis, J. (Retrived 2016). How to record a donation for bookkeeping. Chron Small business accounting and bookkeeping. http://smallbusiness.chron.com/record-donation-bookkeeping-35129.html. (2017)

8. Palmer, H. J., (n,d). Corporate social responsibility and financial performance: Does it pay to be good? (Unpublished Theses. Paper 529). http://scholarship.claremont.edu /cmc_theses/529

9. Sufian, M. A. (2012). Corporate Social Responsibility disclosure in Bangladesh. Global Journals of Management and Business Research 12, 14/1. Global Journals Inc. (USA).

10.Weber, M. (2008). The business case for corporate social responsibility: A company-level

11. Measurement approach for CSR. European Management Journal 26, 247- 261. European School of Management, University of Glasgow www.elsevier.com/locate/emj. 